\title{
Evaluation of Two Consecutive High Sensitivity Cardiac Troponin T Measurements in Healthy Newborns and Newborns with Respiratory Failure
} Sağlıklı Yenidoğanlarda ve Solunum Yetmezliği Olan Yenidoğanlarda Ardışık İki Yüksek Duyarlılıklı Kardiyak Troponin T Ölçümünün Değerlendirilmesi

\section{(D) Sinan Tüfekci1, (D Özgür Kızılca², (D) Aliye Çelikkol33, (D Birol Topçu4}

\begin{abstract}
${ }^{1}$ Tekirdağ Namık Kemal University Faculty of Medicine, Department of Pediatrics, Division of Neonatology, Tekirdağ, Turkey
${ }^{2}$ Tekirdağ Namık Kemal University Faculty of Medicine, Department of Pediatrics, Division of Pediatric Cardiology, Tekirdağ, Turkey

${ }^{3}$ Tekirdağ Namık Kemal University Faculty of Medicine, Department of Biochemistry, Tekirdağ, Turkey

${ }^{4}$ Tekirdağ Namık Kemal University Faculty of Medicine, Department of Bioistatiscs, Tekirdağ, Turkey
\end{abstract}

\section{Abstract}

Objective: Data on the umbilical cord and postnatal physiological limits of the high sensitivity cardiac troponin $\mathrm{T}$ (hs cTnT) in newborns are scarce. This study aims to determine the normal values and upper limits of hs cTnT in healthy newborns. In addition, its clinical significance and usability in neonatal respiratory failure were analyzed.

Method: In this non-invasive and retrospective, cross-sectional study, 113 healthy newborns and 93 newborns with non-cardiac respiratory failure, born between July 2018 and January 2020, were evaluated. Hs cTnT was measured in the umbilical cord and 24-96 $\mathrm{h}$ after birth in infants.

Results: In the healthy group, the median umbilical cord hs cTnT was 38 (17-156) $\mathrm{ng} / \mathrm{L}$ and $99^{\text {th }}$ percentile hs $\mathrm{CTnT}$ was $122 \mathrm{ng} / \mathrm{L}$, and in the respiratory failure group, the median umbilical cord hs CTnT was 72 (27326) ng/L. Postnatal day 2-4 median hs CTnT was 75 (10-194) ng/L and $99^{\text {th }}$ percentile value was $194 \mathrm{ng} / \mathrm{L}$ in the healthy group, and the median $\mathrm{hs}$ cTnT was 145 (41-409) $\mathrm{ng} / \mathrm{L}$ in the respiratory failure group. The calculated area under the ROC curve for umbilical cord hs cTnT was 0.848 [cut-off 64; $95 \%$ confidence interval (Cl); 0.79-0.90: sensitivity $62.4 \%$ specificity 93.7\%], suggesting that umbilical cord hs cTnT is a sensitive marker for the prediction of neonatal respiratory failure. The calculated area under the ROC curve for control hs cTnT was 0.851 (cut-off 121.5; 95\% Cl; 0.790.90 ; sensitivity $71 \%$ specificity $86.8 \%$ ), suggesting that control hs cTnT is a sensitive marker for the prediction of neonatal respiratory failure.

Conclusion: The results show that the reference range of umbilical cord and postnatal hs cTnT in healthy newborns is higher than that in adults. Both hs cTnT values were higher in the neonatal respiratory failure group than those in the healthy group.

Keywords: Healthy newborn, high sensitive cardiac troponin T, neonatal respiratory failure, umbilical cord

\section{Öz}

Amaç: Yenidoğanlarda yüksek duyarlılıklı kardiyak Troponin T'nin (hs cTnT) göbek kordonu ve doğum sonrası fizyolojik sınırlarına ilişkin veriler azdır. Bu çalışma sağlıklı yenidoğanlarda hs cTnT'nin normal değerlerini ve üst sınırlarını belirlemeyi amaçlamaktadır. Ayrıca yenidoğan solunum yetmezliğinde klinik önemi ve kullanılabilirliği analiz edildi.

Yöntem: Bu invazif olmayan ve retrospektif, kesitsel çalışmada, Temmuz 2018 ile Ocak 2020 tarihleri arasında doğan 113 sağlıklı yenidoğan ve kalp dışı kaynaklı solunum yetmezliği olan 93 yenidoğan değerlendirildi. Hs cTnT, bebeklerde göbek kordonunda ve doğumdan 24-96 saat sonra ölçüldü.

Bulgular: Sağlıklı grupta umbilikal kord hs cTnT medyan 38 (17-156) ng/L; 99. persantil hs CTnT $122 \mathrm{ng} / \mathrm{L}$, solunum yetmezliği grubunda umbilikal kord hs cTnT medyan 72 (27-326) ng/L bulundu. Sağlıklı grupta postnatal 2-4 gün hs cTnT medyan 75 (10-194) ng/L; 99. persantil 194 ng/L, solunum yetmezliği grubunda hs cTnT medyan 145 (41-409) idi. Göbek kordonu için hs cTnT ROC eğrisi eğrinin altındaki alan değeri 0,848 [cut-off 64 ; \%95 güven aralığı (GA); 0,79-0,90: duyarlııı \%62,4 özgüllük \%93,7], göbek kordonu hs cTnT'nin yenidoğan solunum yetmezliğinin tahmini için duyarlı bir belirteç olduğunu düşündürmektedir. Kontrol hs cTnT ROC eğrisi eğrinin altındaki alan değeri 0,851 (cut-off 121,5; \%95 GA; 0,79-0,90; duyarlılık \%71 özgüllük \%86,8), kontrol hs cTnT'nin neonatal solunum yetmezliğinin tahmini için duyarlı bir belirteç olduğunu göstermektedir.

Sonuç: Sağlıklı yenidoğanlarda umbilikal kord ve postnatal hs cTnT referans aralığının, erişkin değerlerine göre yüksek olduğu saptanmıştır. Her iki hs cTnT değeri, yenidoğan solunum yetmezliği grubunda sağlıklı gruba göre çok artmıştır.

Anahtar kelimeler: Neonatal pnömoni, sağlıklı yenidoğan, umbilikal kord, yenidoğan geçici takipnesi, yenidoğan respiratuvar distress sendromu, yüksek duyarlııklı kardiyak troponin T

Address for Correspondence: Sinan Tüfekci, Tekirdağ Namık Kemal University Faculty of Medicine, Department of Pediatrics, Division of Neonatology, Tekirdağ, Turkey E-mail: stufekci@nku.edu.tr ORCID: orcid.org/0000-0003-0367-3828 Received: 04.04.2021 Accepted: 02.08.2021

Cite this article as: Tüfekci S, Kızılca Ö, Çelikkol A, Topçu B. Evaluation of Two Consecutive High Sensitivity Cardiac Troponin T Measurements in Healthy Newborns and Newborns with Respiratory Failure. 


\section{Introduction}

Cardiac troponins are protein components of the troponin-tropomyosin complex in the myocardium $(1,2)$. Troponin complex consists of three different subunits that regulate the contractile process in muscle interfering calcium ions. The three subunits are troponin $\mathrm{T}$, which binds to tropomyosin, troponin I, which binds to actin and inhibits the reaction between actin and myosin, and troponin $\mathrm{C}$, which binds to calcium ions. Troponin $\mathrm{I}$ and troponin $\mathrm{T}$ are located in the skeletal and in the heart muscle but are coded to different genes and have a different arrangement of amino acids, which enables the production of antibodies specific to cardiac troponin form and determination in serum. Troponins appear in blood 2-4 $\mathrm{h}$ after insult, peak at about $12 \mathrm{~h}$, and then remain elevated for $7-10$ days $(3,4)$. In newborn, elevated plasma concentrations of hs cTnT decrease to adult level within six months.

Cardiac troponin $\mathrm{T}$ and cardiac troponin $\mathrm{I}(\mathrm{cTnI})$ are released as a result of myocardial cell injury and are highly sensitive biomarkers of myocardial damage. Because cTnI is cleared more rapidly from the circulation than cTnT, its utility as a monitor of ongoing cardiac injury is limited. In healthy terms, cTnT is higher than that in adults $(5,6)$. Troponin $\mathrm{T}$ subunit, which has molecular mass, is $35 \mathrm{kDa}$ and therefore too large to be dispersed freely throughout the placenta. It is thought that there is no transplacental transmission. In the newborns, cTnT is most commonly used to determine cardiac stress associated with patent ductus arteriosus and neonatal asphyxia (7-9). However, reference ranges have not been exactly defined for newborns, which makes the interpretation of elevated cTnT values very difficult. If high cTnT values are incorrectly interpreted as abnormal, this may lead to unnecessary interventions. Because 99th percentile cTnT in healthy adults provides better sensitivity in individuals suspected of having acute coronary syndrome, the use of hs cTnT test has recently been recommended when analyzing cTnT. According to the guidelines, hs cTnT values $>14 \mathrm{ng} / \mathrm{L}$ are considered pathological in adults (10). This study primarily aimed to determine the distribution of the umbilical cord and postnatal day 2-4 hs cTnT in healthy newborns. The secondary aim was to investigate the diagnostic value and clinical significance of hs cTnT measurements in newborns with respiratory failure.

\section{Material and Methods}

\section{Patients and Study Design}

A total of 206 late preterm (at gestational week $34^{0 / 7}-36^{6 / 7}$ ) and term (at gestational week $37^{0 / 7}-41^{6 / 7}$ ) infants born between July 2018 and January 2020 were included in the study. Of the patients, 113 were healthy infants (group 1 , control group) and 93 were infants with postnatal newborn respiratory distress syndrome (group 2, patient group). Blood gas and hs cTnT levels were analyzed in the blood taken from the umbilical cord artery and/ or vein within the first $10 \mathrm{~min}$ after birth. Gestational weeks, birth weight, 1- and 5-minute Apgar scores, maternal age, gender, mode of delivery, and the need for mechanical ventilation in group 2 patients were investigated. Patients in group 1 with suspected heart disease during physical examination and all infants in group 2 were examined by a pediatric cardiologist at postnatal day 2-4, in terms of heart failure, congenital structural heart diseases, persistent pulmonary hypertension, patent ductus arteriosus, and myocarditis via physical examination, electrocardiography, and echocardiographic examination. Infants with cardiac problems were excluded from the study.

Other exclusion criteria were as follows: infants born before gestational week 34 and after gestational week 42 , patients with stage 2-3 hypoxic ischemic encephalopathy, acute renal failure, neonatal sepsis, congenital anomalies, preeclampsia in the maternal history, maternal hypertension ( $>140 / 90 \mathrm{mmHg}$ ), and infants of mothers who required tocolysis and magnesium treatment.

Patients diagnosed with transient tachypnea of the newborn, neonatal respiratory distress syndrome, and neonatal pneumonia were included in the subgroups of neonatal respiratory failure. Differential diagnoses were made by a neonatologist according to the diagnostic guidelines based on the results of chest radiography, thoracic ultrasound, blood gas, blood culture, laboratory parameters, and clinical evaluation (11).

\section{Sample Collection}

In the first $10 \mathrm{~min}$ after birth, $0.5 \mathrm{~mL}$ of blood was taken from the umbilical cord artery and/or vein in a lithium heparin tube, and blood gas was analyzed within the first $15 \mathrm{~min}$. Control hs cTnT was taken from venous blood after 2-4 days postnatally. Hs cTnT was analyzed within the first hour in the accredited laboratory of our hospital. Analysis of cTnT was performed using the electrochemiluminescence method (Cobas e602, Roche Diagnostics) as a high- 
sensitivity cTnT test and its unit was measured in $\mathrm{ng} / \mathrm{L}$ (detection limit 5-10.000 ng/L).

\section{Perinatal Factors}

Naegele's formula was used in pregnant women whose gestational age was determined according to the pregnancy ultrasound performed at the beginning of the second trimester or in pregnant women who did not undergo ultrasound in the same period. The results of $\mathrm{pH}$, base excess, and lactate in umbilical cord artery and/or vein blood were recorded in the first 10 min after delivery.

\section{Ethical Approval}

This study was a retrospective analysis of prospectively collected data. It is a cross-sectional study approved by the Tekirdağ Namık Kemal University Ethics Committee and it was conducted according to the principles of the Helsinki Declaration (protocol number:2020.14.01.14).

\section{Statistical Analysis}

Statistical analyses were performed using Statistical Package for Social Sciences version 17.0 software. The normality of distribution of the variables was examined using histogram graphs and the Kolmogorov-Smirnov test. Median (interquartile range), minimum, and maximum values were used for descriptive analyses. Categorical variables were compared using the Pearson's chi-square test. The Mann-Whitney $U$ test was used to evaluate non-parametric variables between two groups, and the
Kruskal-Wallis test was employed when the evaluation was performed between more than two groups. The Spearman's rank correlation test was used in the analysis of the measurement data with each other. The changes in the hs cTnT values were examined within the group using the Wilcoxon test, while they were analyzed by repeated measures analysis between the groups. Note that $\mathrm{p}<0.05$ was considered statistically significant.

\section{Results}

A total of 206 newborns, 113 in the healthy group and 93 in the neonatal respiratory failure group, were included in the study. A total of 69 (33.5\%) babies were born latepreterm, including 21 (18.6\%) infants in the healthy group and $48(51.6 \%)$ infants in the patient group. There was no significant difference between the groups in terms of maternal age, 1- and 5- min Apgar scores, birth weight, and umbilical cord $\mathrm{pH}(\mathrm{p}>0.05)$. Base excess and lactate were lower in the healthy group compared to those in the patient group $(\mathrm{p}=0.02, \mathrm{p}<0.01)$ (Table 1$)$.

\section{Healthy Group}

Of the 113 patients, $59.56 \%$ were female, $18.58 \%$ were born late-preterm, and $88.5 \%$ were born via the surgical method (mostly repetitive cesarean delivery). The median umbilical cord hs cTnT was 38 (17-156) ng/L and the median hs cTnT was 75 (10-194) ng/L at postnatal 24-96 h. In healthy infants, the 99th percentile umbilical cord Table 1. Demographic data in healthy newborns and patients

\begin{tabular}{|c|c|c|c|c|c|c|}
\hline \multirow[t]{2}{*}{ Feature } & \multicolumn{2}{|c|}{$\begin{array}{l}\text { Healthy group } \\
(n=113)\end{array}$} & \multicolumn{2}{|c|}{$\begin{array}{l}\text { Patient group } \\
(n=93)\end{array}$} & \multicolumn{2}{|c|}{$\begin{array}{l}\text { Total } \\
(n=206)\end{array}$} \\
\hline & $\mathbf{n}$ & $\%$ & $\mathbf{n}$ & $\%$ & $\mathbf{n}$ & $\%$ \\
\hline Female & 56 & 49.5 & 45 & 48.4 & 101 & 49 \\
\hline Male & 57 & 50.5 & 48 & 51.6 & 105 & 51 \\
\hline Vaginal delivery & 13 & 11.5 & 15 & 16.1 & 28 & 13.6 \\
\hline Cesarean & 100 & 88.5 & 78 & 83.9 & 178 & 86.4 \\
\hline Late preterm & 21 & 18.6 & 48 & 51.6 & 69 & 33.5 \\
\hline \multirow[t]{2}{*}{ Term } & 92 & 81.4 & 45 & 48.3 & 137 & 66.5 \\
\hline & Median & $\begin{array}{l}\text { Minimum- } \\
\text { maximum }\end{array}$ & Median & $\begin{array}{l}\text { Minimum- } \\
\text { maximum }\end{array}$ & $\mathbf{p}$ & \\
\hline Maternal age & 28 & $15-41$ & 30 & $18-45$ & 0.35 & \\
\hline Gestational age (weeks) & 38 & $34-39$ & 37 & $34-42$ & 0.13 & \\
\hline Birth weight (gram) & 3.110 & $1.760-3.800$ & 2910 & $1.800-4.100$ & 0.07 & \\
\hline Apgar 1. minute & 8 & $3-9$ & 8 & $4-9$ & 0.80 & \\
\hline Apgar 5. minute & 9 & $7-10$ & 9 & $7-10$ & 0.07 & \\
\hline Umbilical cord pH & 7.35 & $7.18-7.45$ & 7.35 & $7.05-7.56$ & 0.50 & \\
\hline Base excess (mmol/L) & -3 & $-10-3.6$ & -3.6 & $-15-4.7$ & 0.02 & \\
\hline Lactate $(\mathrm{mmol} / \mathrm{L})$ & 1.91 & $1.1-7.4$ & 2.63 & $1.07-10.18$ & $<0.01$ & \\
\hline
\end{tabular}


hs cTnT was $122 \mathrm{ng} / \mathrm{L}$, and the control 99th percentile hs cTnT was $194 \mathrm{ng} / \mathrm{L}$ after 24-96 h. There was no statistically significant difference found in the results based on the mode of delivery; however, the increase in follow-up hs TnT after cesarean section was significant $(\mathrm{p}<0.01)$. Umbilical cord and follow-up hs cTnT values for preterm infants were higher than in term babies; however, no statistically significant difference was present $(\mathrm{p}=0.22$, $\mathrm{p}=0.14)$ (Table 2).

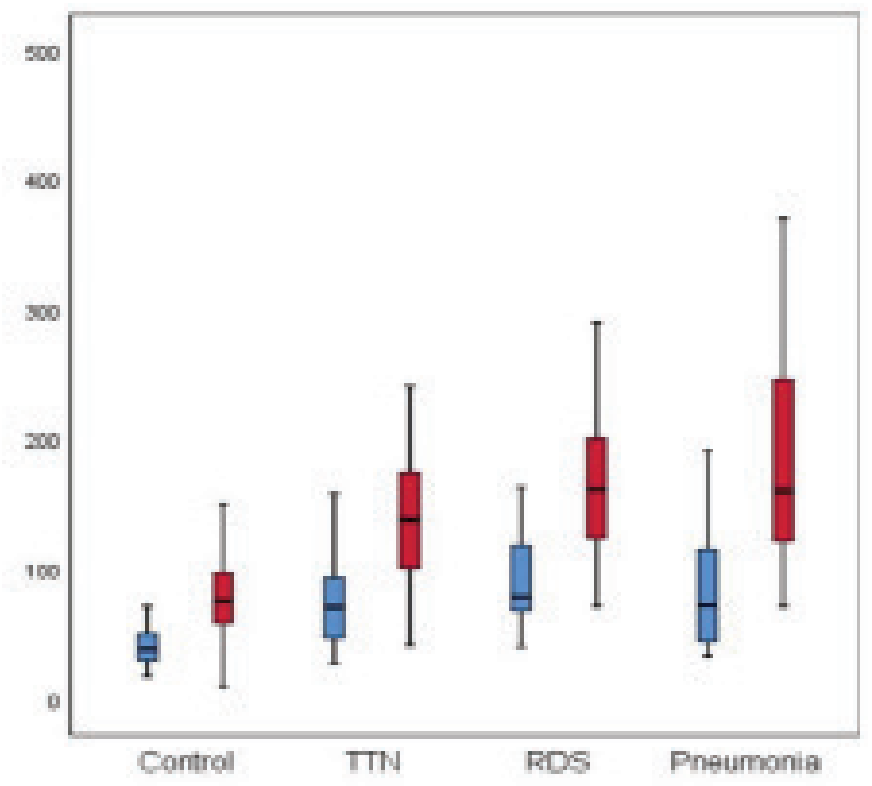

cend as etet

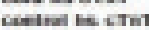

Figure 1. Hs cTnT in neonatal respiratory failure subgroups and control groups

Hs cTnT: High sensitivity cardiac troponin T, TTN: Transient tachypnea of the newborn, RDS: Respiratory distress syndrome

\section{Neonatal Respiratory Failure Group}

Of the 93 patients, 48 (51.61\%) were male. Of the infants, $51.61 \%$ were born late-preterm and $83.87 \%$ by cesarean section. Late-preterm birth rate was higher in the patient group than in the healthy group. In newborns with respiratory distress, both of median hs cTnT results were higher than those of the control group $(\mathrm{p}<0.01)$ (Figure 1). Furthermore, we observed that the change between the umbilical cord hs cTnT and follow-up hs cTnT in patients with respiratory failure increased more than that in the control group $(\mathrm{p}<0.01)$. Umbilical cord hs cTnT was higher in late preterms/term with respiratory failure than that in healthy late-preterm/term infants $(\mathrm{p}<0.01)$. In addition, postnatal follow-up hs cTnT was higher in late-preterms/ term with respiratory failure than that in healthy preterms/ term $(\mathrm{p}<0.01)$. Both measurements of hs cTnT were higher in term babies than in late-preterm babies in the patient group; however, the difference was not statistically significant ( $\mathrm{p}=0.54, \mathrm{p}=0.32$ ). Calculated area under the ROC curve for umbilical cord hs cTnT was 0.848 [cut-off 64; 95\% confidence interval (CI); 0.79-0.90: sensitivity $62.4 \%$, specificity $93.7 \%$ ], suggesting that umbilical cord hs cTnT is a sensitive marker for the prediction of neonatal respiratory failure. Calculated area under the ROC curve for control hs cTnT was 0.851 (cut-off 121.5; 95\% CI: 0.79-0.90; sensitivity $71 \%$, specificity $86.8 \%$ ), suggesting that control hs cTnT is a sensitive marker for the prediction of neonatal respiratory failure (Table 3, Figure 2).

\section{Transient Tachypnea of the Newborn}

The median gestational week of the patients was 38 (34$41)$, and their median birth weight was 3.002 (2.020-3.945) gram. The median umbilical cord hs cTnT and the median follow-up hs cTnT results were higher in the patient group than those in the healthy control group $(\mathrm{p}<0.01)$.

Table 2. Hs cTnT by mode of delivery and gestational week in healthy newborns

\begin{tabular}{|c|c|c|c|c|c|}
\hline Features & & Median & P 25 & P 75 & $\mathbf{p}$ \\
\hline \multirow{2}{*}{ Vaginal delivery } & Umbilical cord & 41.50 & 37.50 & 48.50 & \multirow{2}{*}{0.13} \\
\hline & Control & 66.00 & 58.00 & 117.00 & \\
\hline Caesarean section & Control & 75.50 & 58.50 & 96.50 & $<0.01$ \\
\hline Late preterm & Umbilical cord & 39.00 & 37.00 & 47.00 & 0.01 \\
\hline Term & Control & 73.00 & 57.00 & 94.00 & $<0.01$ \\
\hline \multirow{2}{*}{ Total } & Umbilical cord & 38.00 & 30.00 & 50.00 & \multirow{2}{*}{$<0.01$} \\
\hline & Control & 75.00 & 58.00 & 97.00 & \\
\hline
\end{tabular}

Hs cTnT: High sensitive cardiac troponin T 


\section{Respiratory Distress Syndrome}

The median gestational week of the patients was 35 (3437 ), and their median birth weight was 2.397 (1.800-3.400) gram. All were late-preterm infants. In patients, the median umbilical cord hs cTnT and the median follow-up hs cTnT were higher than those in the healthy group $(\mathrm{p}<0.01)$.

\section{Neonatal Pneumonia}

The median gestational week of the patients was 38 (35$41)$, and their median birth weight was 3.410 (2.390-4.100)
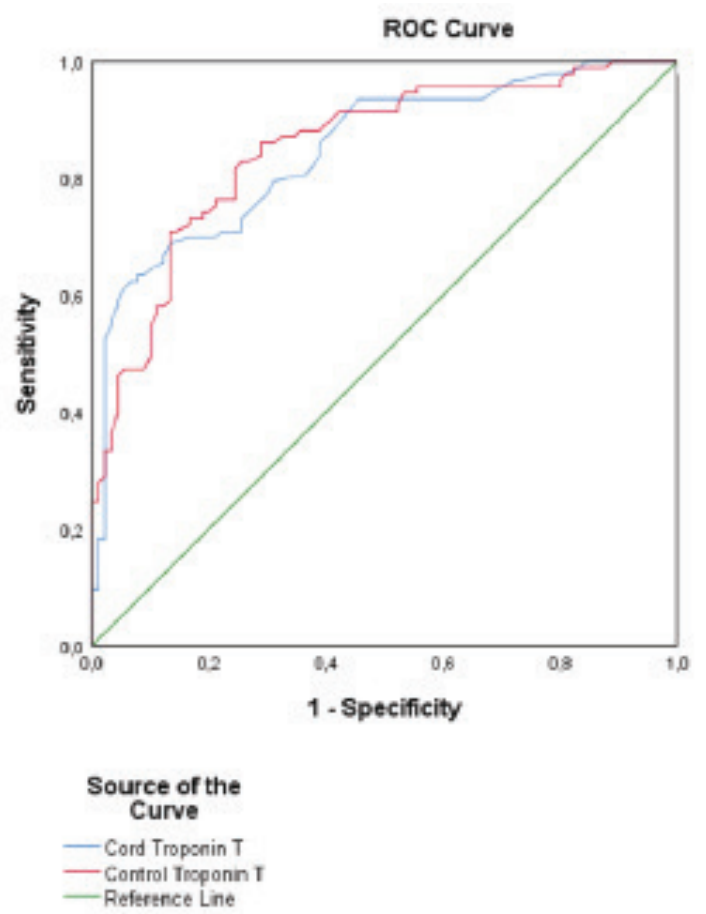

Figure 2. Predictive value of hs cTnT ROC analysis for neonatal respiratory failure group: sensitivity and specificity

Hs cTnT: High sensitivity cardiac troponin T gram. The median umbilical cord hs cTnT and postnatal median follow-up hs cTnT were higher than those of the healthy group $(\mathrm{p}<0.001)$ (Table 4$)$. Hs cTnT ROC analysis in the patient subgroup is shown in Table 3.

A positive Pearson correlation was noted between the need for a mechanical ventilator and the umbilical cord and postnatal follow-up hs cTnT in patients hospitalized for respiratory failure. Because both hs cTnT values increased in the patients, the need for mechanical ventilation also increased $(r=0.387, \mathrm{p}<0.01, \mathrm{r}=0.388, \mathrm{p}<0.01)$.

\section{Discussion}

To the best of our knowledge, this study is the first one involving the measurements of hs cTnT at two separate time points in late-preterm/term newborns who are healthy and have respiratory failure.

\section{Healthy Group}

Compared to the healthy adult population, hs cTnT was higher in both healthy newborns and in newborns with respiratory distress. This study presents the reference range of hs cTnT in the umbilical cord and postnatal day 2-4 in healthy newborns. The 99th percentile umbilical cord hs cTnT was $65 \mathrm{ng} / \mathrm{L}$, and postnatal the 99th percentile follow-up hs cTnT was $150 \mathrm{ng} / \mathrm{L}$, which was higher than the results for the adult population (12). Hs cTnT significantly increases following delivery, and this is known to be normal for the neonatal period. Awada et al. (13) found that the 99th percentile value of cTnT measured using the classical method was $244 \mathrm{ng} / \mathrm{L}$ after birth in healthy infants. In Karlen's study on 158 healthy term newborns, the median umbilical cord hs cTnT was $34 \mathrm{ng} / \mathrm{L}$ (interquartile range: 26 44 ) and the 99th percentile value was $88 \mathrm{ng} / \mathrm{L}$ (14). In their study, the follow-up hs cTnT after 2-5 days was 92 (median; interquartile range: 54-158) $\mathrm{ng} / \mathrm{L}$ and the 99th percentile

\begin{tabular}{|c|c|c|c|c|c|c|c|c|c|}
\hline Hs cTnT & & AUC & $\mathbf{p}$ & $95 \% \mathrm{Cl}$ & Cutt-off & $\begin{array}{l}\text { Sensitivity } \\
(\%)\end{array}$ & $\begin{array}{l}\text { Specificity } \\
(\%)\end{array}$ & PPD (\%) & $\begin{array}{l}\text { NPD } \\
(\%)\end{array}$ \\
\hline \multirow{2}{*}{ TTN } & UC & 0.830 & $<0.01$ & $0.75-0.90$ & 54 & 68 & 86.6 & 69.4 & 85.8 \\
\hline & Control & 0.824 & $<0.01$ & $0.75-0.89$ & 96.5 & 82 & 74.7 & 64.0 & 88.3 \\
\hline \multirow{2}{*}{ RDS } & UC & 0.919 & $<0.01$ & $0.85-0.98$ & 63.5 & 80.9 & 93.7 & 70.8 & 96.3 \\
\hline & Control & 0.894 & $<0.01$ & $0.82-0.96$ & 109 & 85.7 & 79.1 & 48.6 & 96 \\
\hline NP & Control & 0.902 & $<0.01$ & $0.83-0.97$ & 92 & 95 & 71.4 & 42.2 & 98.5 \\
\hline \multirow{2}{*}{ All patient } & UC & 0.848 & $<0.01$ & $0.79-0.90$ & 64 & 62.4 & 93.7 & 89.2 & 75.0 \\
\hline & Control & 0.851 & $<0.01$ & $0.79-0.90$ & 121.5 & 71 & 86.8 & 84.6 & 74.5 \\
\hline
\end{tabular}

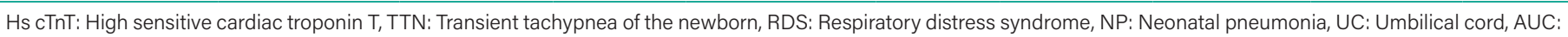

Area under curve, $\mathrm{Cl}$ : Confidence interval, PPD: Positive predictive value, NPD: Negative predictive value 
Table 4. Umbilical cord and follow-up hs cTnT in the healthy and patient groups

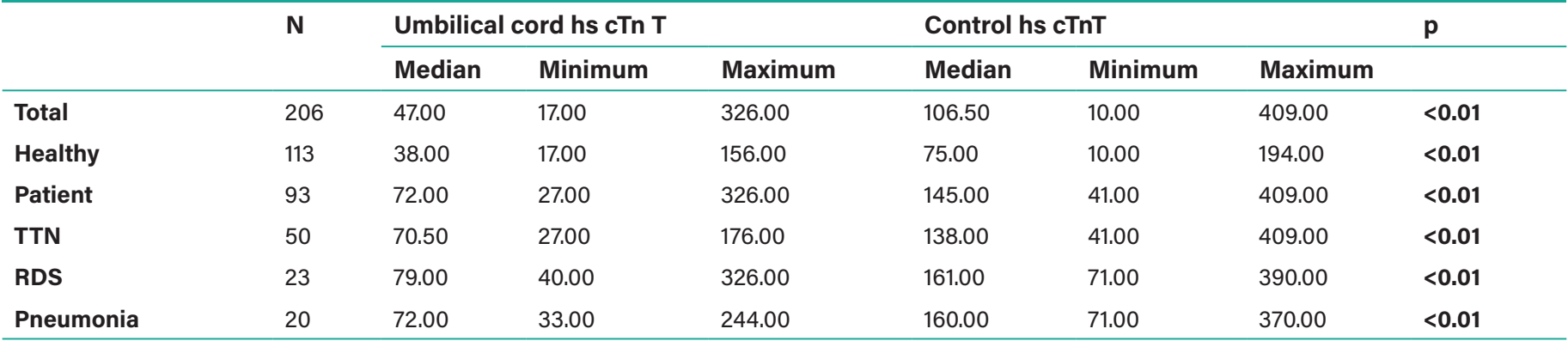

TTN: Transient tachypnea of the newborn, RDS: Respiratory distress syndrome, Hs cTnT: High sensitive cardiac troponin T

value was $664 \mathrm{ng} / \mathrm{L}$. However, Karlen's study did not include late-preterm babies. Moreover, their results were close to the mean umbilical cord and follow-up hs cTnT values of the healthy group in the present study. In a study by Jehlicka on umbilical cord or venous blood involving 241 healthy term newborns, the median hs cTnT was $38.2 \mathrm{ng} / \mathrm{L}$ and the 97.5th percentile value was $83 \mathrm{ng} / \mathrm{L}$ (CI: 74.1-106.9) (6). Most of the cTnT results obtained by conventional methods in healthy newborns were consistent with the present study. However, some previous studies in literature have yielded different results $(5,7,15,16)$.

\section{Causes of Elevated Umbilical Cord and Follow-up hs cTnT}

It is possible to speculate that the functional hypoxemia of the fetus coupled with the added cardiovascular stress at the time of delivery leads to scanty myocyte loss within the heart and that in some babies, it causes high levels of cardiac troponin $\mathrm{T}$, without clinical cardiorespiratory compromise (17). In an isolated heart rat model, chemically induced cardiac myocyte membrane damage caused the release of cardiac troponin $\mathrm{T}$ without myocardial necrosis. Therefore, it is possible to speculate that membrane disruption, without cell death, could lead to a small and transient rise of cardiac troponin $\mathrm{T}$ (18).

Differences in cTnT according to the mode of delivery in term newborns have been investigated in only a few studies, and the results are varied. In most of the studies, no significant difference has been found in cTnT values according to the mode of delivery $(14,15,19,20)$. In patients in the healthy group, the significant increase in control hs cTnT after cesarean delivery may be misleading due to the low number of normal births (gynecology unit is a reference center for repeated cesarean deliveries and high risk pregnant women in a region with a population of 1.5 million people).

In the present study, $18.58 \%$ of healthy newborns were late-preterm and both measurements of the mean hs
cTnT values were slightly higher than those in term babies. Previous studies have shown that cTnT was higher at baseline in premature infants than in healthy term infants. In a study involving 22 preterm patients born at 22-25 weeks, the mean cTnT was found to be 170 (0310) ng/L (17). Our study did not include early-preterm infants.

In the present study, no significant correlation was found among maternal age, birth weight, 1- and 5- min apgar scores, umbilical cord blood gas $\mathrm{pH}$ values, and both hs cTnT levels in the patient and control groups. Base excess and lactate levels were lower in healthy newborns then in patients with respiratory distress $(\mathrm{p}=0.026, \mathrm{p}<0.001)$. These results were similar to those obtained in literature $(5,7,21)$.

Herein, no difference was found in umbilical cord hs cTnT levels in terms of gender. However, both hs cTnT levels were higher in male patients in the neonatal respiratory distress group. Although the results from three different studies including healthy newborns were in favor of male newborns $(6,14,15)$, no gender-related difference was found in many other studies $(5,9,13,20)$.

\section{Neonatal Respiratory Failure Group}

Respiratory distress syndrome; in a study of 46 patients, 26 preterm infants with RDS born at the gestational week $\leq 32$ were compared with 20 infants without RDS. C TnT was high in the group with RDS on postnatal day 2 (16). In 113 healthy term infants and 49 preterm infants with respiratory distress, umbilical cord cTnT was found to be higher in infants with RDS compared to that in healthy term infants (5) A study involving 116 healthy infants and 48 infants with respiratory distress showed that the postnatal cTnT levels were higher in infants with RDS than those in healthy infants (13). Although conventional measurement methods were used in previous publications, the elevated cTnT level in infants with RDS was consistent with our results. The median hs cTnT values for both measurements were found 
to be twice as higher in our patients with RDS than in the healthy group $(\mathrm{p}<0.01)$.

An hs cTnT study including two separate measurements was performed for the first time in patients with TTN. In 50 patients, the umbilical cord and postnatal day 2-4 hs cTnT were higher than those in the control group. In a study conducted with the conventional method, cTnT was found to be higher in 11 patients with TTN than that in the control group in the first $48 \mathrm{~h}$ after birth, similar to the results of the present study. An hs cTnT study was performed for the first time in patients with NP. In 20 patients, the umbilical cord and postnatal day 2-4 hs cTnT levels were higher than those in the control group. In a study conducted with the conventional method in 27 patients with NP, cTnT in the first $48 \mathrm{~h}$ after birth was found to be higher than in the control group (22).

\section{Causes of Elevated hs cTnT}

These increased concentrations could be related to the fact that primary respiratory diseases may lead to myocardial injury either through the decrease in cardiac output associated with mechanical ventilation or through cellular dysfunction leading to poor handling of oxygen, which leads to elevated cardiac biomarkers. Hs cTnT elevations may be associated with minimal myocardial histological changes that cannot be detected on echocardiography and electrocardiography $(7,23)$. The exact cause or causes are still not fully known.

In the adult acute RDS study, cTnT elevation levels were found to be associated with adverse outcomes, such as death, multiple organ failure, and the need for a mechanical ventilator (24). Studies on this subject in the neonatal period are limited; however, a relationship was found between hs cTnT levels and the need for a mechanical ventilator in the present study. As hs cTnT values increase in patients, the need for mechanical ventilation increases. Adverse outcomes, such as multiple organ failure and death, were not observed in our patients. In the study of Awada et al. (13), a positive correlation was found between the duration of mechanical ventilation and cTnT levels in the neonatal period. Further studies are needed to determine the relationship between hs cTnT and multiple organ failure, death, and the need for mechanical ventilation in preterm and term newborns.

\section{Strengths and Limitations of the Study}

The present study includes late-preterm/term newborns who are healthy and have neonatal respiratory distress, and the number of patients and study planning are quite favorable. Furthermore, the study includes test results and clinical evaluations. Hs cTnT was measured twice in the umbilical cord and on postnatal day $2-4$, and the results showed a significant increase in the postnatal period. Hs cTnT was investigated in three diseases that most commonly caused respiratory failure in newborns.

\section{Study Limitations}

Limitations of this study are as follows: this is a singlecenter study; early preterm babies were excluded; the need for inotrope with mean blood pressure measurements, and long-term hs cTnT measurements beyond two weeks were not included.

\section{Conclusion}

We believe that the hs cTnT test will give more sensitive results in the cardiovascular adaptation process in newborns, in healthy babies and/or babies with respiratory failure. This study shows that umbilical cord and postnatal hs cTnT levels are significantly higher in RDS, TTN, and NP than in healthy newborns. These results suggest that even if there is no structural heart disease, the heart is affected in neonatal respiratory distress. The wide range in hs cTnT levels observed in healthy late-preterm/term infants in this study underlines the need for caution when using hs cTnT levels to evaluate cardiac insult in newborn infants.

\section{Ethics}

Ethics Committee Approval: It is a cross-sectional study approved by the Tekirdağ Namık Kemal University Ethics Committee and it was conducted according to the principles of the Helsinki Declaration (protocol number:2020.14.01.14).

Informed Consent: Family signature is not required in retrospective studies.

Peer-review: Externally peer-reviewed.

\section{Authorship Contributions}

Concept: S.T., Design: S.T., Ö.K., A.Ç., Data Collection or Processing: S.T., A.Ç., Analysis or Interpretation: S.T., B.T., Literature Review: S.T., Ö.K., B.T., Writing: S.T., Ö.K., Manuscript Review and Revisation: S.T., A.Ç., B.T.

Conflict of Interest: No conflict of interest was declared by the authors.

Financial Disclosure: The authors declared that this study received no financial support. 


\section{References}

1. Bettencourt P. NT-proBNP and BNP: biomarkers for heart failure management. Eur J Heart Fail 2004;6(3):359-363.

2. Bhayana V, Henderson AR. Biochemical markers of myocardial damage. Clin Biochem 1995;28(1):1-29.

3. Simovic A, Stojkovic A. Correlation level of cardiac troponin-i with total duration of oxygen / ventilator therapy in the term newborns with respiratory distress. J Cardiovasc Dis Diagn 2014;2:5.

4. Braunwald E, Fauci AS, Kasper DL. Harrison's Principles of Internal Medicine, 15th ed. New York: McGraw-Hill; 2001.

5. Clark SJ, Newland P, Yoxall CW, Subhedar NV. Cardiac troponin T in cord blood. Arch Dis Child Fetal Neonatal Ed 2001;84(1):F34-F37. doi: 10.1136/fn.84.1.f34.

6. Jehlicka P, Huml M, Rajdl D, Mockova A, Matas M, Dort J, et al. How to interpret elevated plasmatic level of high-sensitive troponin $\mathrm{T}$ in newborns and infants? Physiol Res 2018;67(2):191-195.

7. Clark SJ, Newland P, Yoxall CW, Subhedar NV. Concentrations of cardiac troponin $\mathrm{T}$ in neonates with and without respiratory distress. Arch Dis Child Fetal Neonatal Ed 2004;89(4):F348-F52. doi: 10.1136/adc.2002.025478.

8. Joseph S, Kumar S, Ahamed MZ, Lakshmi S. Cardiac troponin T as a marker of myocardial dysfunction in term neonates with perinatal asphyxia. Indian J Pediatr 2018;85(10):877-884.

9. El-Khuffash AF, Molloy EJ. Influence of a patent ductus arteriosus on cardiac troponin $\mathrm{T}$ levels in preterm infants. J Pediatr 2008;153(3):350-353.

10. Thygesen K, Alpert JS, Jaffe AS, Chaitman BR, Bax JJ, Morrow DA, et al; Executive Group on behalf of the Joint European Society of Cardiology (ESC) /American College of Cardiology (ACC) /American Heart Association (AHA)/World Heart Federation (WHF) Task Force for the Universal Definition of Myocardial Infarction. Fourth universal definition of myocardial infarction (2018). Circulation 2018;138(20):e618-e651. doi: 10.1161/CIR.0000000000000617.

11. Sweet DG, Carnielli V, Greisen G, Hallman M, Ozek E, Te Pas A, et al. European Consensus Guidelines on the management of respiratory distress syndrome - 2019 update. Neonatology 2019;115(4):432-450.

12. Giannitsis E, Kurz K, Hallermayer K, Jarausch J, Jaffe AS, Katus HA. Analytical validation of a high-sensitivity cardiac troponin $\mathrm{T}$ assay. Clin Chem 2010;56(2):254-261.
13. Awada H, Al-Tannir M, Ziade MF, Alameh J, El Rajab M. Cardiac troponin T: a useful early marker for cardiac and respiratory dysfunction in neonates. Neonatology 2017;92(2):105-110.

14. Karlén J, Karlsson M, Eliasson H, Bonamy AE, Halvorsen CP. Cardiac troponin $\mathrm{t}$ in healthy full-term infants. Pediatr Cardiol 2019;40(8):1645-1654.

15. Baum H, Hinze A, Bartels P, Neumeier D. Reference values for cardiac troponins $\mathrm{T}$ and $\mathrm{I}$ in healthy neonates. Clin Biochem 2004;37:1079-1082.

16. Trevisanuto D, Zaninotto M, Altinier S, Plebani M, Zanardo V. High serum cardiac troponin $\mathrm{T}$ concentrations in preterm infants with respiratory distress syndrome. Acta Paediatr 2000;89:1134-1146.

17. Fortunato G, Ciarrusso GP, Martinelli P, Sglavo G, Vassallo M, Tomeo $\mathrm{L}$, et al. Cardiac troponin $\mathrm{T}$ and amino-terminal pro-natriuretic peptide concentrations in fetuses in the second trimester and in healthy neonates. Clin Chem Lab Med 2006;44(7):834-836.

18. Remppis A, Scheffold T, Greten J. Intracellular compartmentation of troponin T: release kinetics after global ischaemia and calcium paradox in the isolated perfused rat heart. J Moll Cell Cardiol 1995;27(2):793-803.

19. Shiva R, Maryam R, Hajie B. Cardiac troponin T levels of umbilical cord in neonates with abnormal fetal heart rate. Iran J Pediatr 2013;23(1):85-88.

20. Lipshultz SE, Simbre VC, Hart S, Rifai N, Lipsitz SR, Reubens L, et al. Frequency of elevations in markers of cardiomyocyte damage in otherwise healthy newborns. Am J Cardiol 2008;102(6):761-766.

21. El-Khuffash AF, Molly AJ. Serum troponin in neonatal intensive care. Neonatology 2008;94(1):1-7.

22. Fahmeya SS, Fathya H, Gabalb KA, Khairya H. Cardiac troponin $\mathrm{T}$ in neonates with respiratory distress. Gaz Egypt Paediatr Assoc 2018;66(4):100-102.

23. Anderson PA, Greig A, Mark T, Malouf NN, Oakeley AE, Ungerleider $\mathrm{RM}$, et al. Molecular basis of human cardiac troponin T isoforms expressed in the developing, adult, and failing heart. Circ Res 1995;76(4):681-686

24. Rivara MB, Bajwa EK, Januzzi JL, Gong MN, Thompson BT, Christiani DC. Prognostic significance of elevated cardiac troponin-T levels in acute respiratory distress syndrome patients. PLoS One 2012;7(7):e40515. doi: 10.1371/journal.pone.0040515. 